\title{
Doğum Eyleminde Beslenme
}

Oral Nutrition During Birth

\section{Emine KOÇ ${ }^{1}$, Nevin ŞAHIIN ${ }^{2}$}

1. Ondokuz Mayıs Üniversitesi, Sağlık Bilimleri Fakültesi, Samsun

2. Istanbul Üniversitesi Florence Nightingale Hemşirelik Fakültesi, İstanbul

\section{$\ddot{O Z E T}$}

Doğum eylemi doğal bir süreçtir. Bu süreçte yapılan yanlış veya gereksiz uygulamalar doğumun doğallı̆̆ını bozabilmekte, annede ketosiz, ketosiz ile ilişkili uzamış eylem, dehidratasyon, müdahaleli doğum ve doğum sonu kanamaya neden olurken, fetüste hipogilisemi, hiponatremi gibi bazı komplikasyonların gelismesine neden olabilmektedir. Doğum eyleminin doğallığının korunup sağlıklı bir şekilde ilerleyebilmesi için kanıt temelli çalışma sonuçları ile sağlık hizmetlerinin standartlaşmasına ihtiyaç duyulmaktadır. Kadının doğum eylemi sirasında gereksinimi olan enerjinin karşılanması konusunda da birçok ülkede farklı politikalar uygulanmaktadır. Amerika Birleşik Devletleri, Kanada, Ingiltere, Avustralya ve birçok Avrupa ülkelerinin çeșitli merkezlerinde doğum eylemi sirasinda oral beslenme kisitlanmazken, ülkemizde oral beslenme kisitlanıp, kadının enerji ihtiyacı parenteral yolla karşılanmaya çalışılmaktadır. Bu derlemede; ïlkemizde yaygın olarak uygulanan ăgıdan sivi ve besin alıminin sinırlandırllmasinin anne ve bebek açısından değerlendirilmesi, bu konuda kanita dayalı tıp uygulamaları ve doğum eyleminde kadının beslenme gereksinimleri incelenecektir. Bununla birlikte; doğum eyleminde destek ve bakım sağlayıcılarda farkındalık sağlanması ve uygulamalara yol göstermesi hedeflenmektedir.

Anahtar Kelimeler: doğum; yeme; içim; oral beslenme; kanita dayalı tıp

\section{ABSTRACT}

Giving birth is a natural process. Some faulty or unnecessary practices during this process may spoil the naturalness of birth and cause ketosen, ketosen associated with prolonged labor, dehydration, assisted delivery and postpartum hemorrhage to develop in the mother and hipogilise, hpyponetremia and some complications in the fetus. To ensure a natural birth and to let it proceed in a healthy process, it is necessary that health services are standardized in line with results from evidence based practices. Many countries follow different policies in the meeting of the energy needed by women while giving birth. While oral nutrition is not limited during birth in America, Canada, England and various centers in several European countries, Ours country restrict oral nutrition and women's energy need is met via parenteral nutrition. This paper evaluates the prevalent restriction in the oral administration of liquids and food in our country in terms of the mother and the baby and inspect evidence based practices in this issue as well as the nourishment requirements of women during child birth. In addition, it aims to raise awareness in support and care providers to women and guide the practices.

Keywords: labor; eating; drinking; parenteral feeding; evidence-based medicine

\footnotetext{
İletişim:

Sorumlu Yazar: Emine KOÇ

Adres: Ondokuz Mayıs Üniversitesi, Sağlık Yüksek Okulu,

Kurupelit Kampüsü, 55270, Samsun

Tel: +90 (0362) 3121919

E-Posta: emine_koc555@hotmail.com

Makale Geliş: 12.11 .2015

Makale Kabul: 20.03.2016

DOI: http://dx.doi.org/10.16948/zktipb.237170
}

\section{GíRIŞ}

Doğum eylemi; düzenli gelip giden, rahatsız edici-sancilı uterus kasılmalarının, serviksin efasmanına ve dilatasyonuna yol açtığ 1 fizyolojik bir süreçtir. Doğum eyleminin birinci evresi, silinme ve dilatasyon evresi olup kendi içinde 3 fazdan oluşmaktadır. Latent faz (dilatasyon $3 \mathrm{~cm}$ ) ortalama 12 saat, aktif faz (dilatasyon $4-7 \mathrm{~cm}$ ) ortalama 4 saat ve geçiş fazı $(8-10 \mathrm{~cm})$ ortalama 2 saat sürmektedir. Doğum eyleminin birinci evresinin süresi bir çok faktöre bağlı olup bazı kadınlarda bu süreç daha da uzayabilmektedir. Bununla birlikte kadının doğum sürecinde ciddi fiziksel çabaya girmeden önce, bol miktarda karbonhidrat, protein ve siv1 tüketilmesi tavsiye edilmektedir. Ancak doğum eyleminde beslenmeyle ilgili farklı prosedürler uygulanabilmektedir [1].

Doğum eyleminde yer alan çoğu ebe; gebe kadının "ne olur bir damla su" diye yalvard1ğına şahit olmuştur. Bu durumda ebeler çoğu zaman kadın doğum uzmanın direktifi üzerine bu yalvarışa kayıtsız kalabilmektedir ya da bazen gebe bireyin dudağını pamukla islatarak onu rahatlatmaya çalışmaktadır. Bazen ise beslenmenin yasak olduğunu söyleyip ağrıdan yorgun düșen kadın için doğum olayının daha da travmatik hale gelmesine, sağlik çalışanlarına karşı olumsuz duygularının artmasına neden olabilmektedir. Bazi ebeler ise oral beslenmenin bulantı kusmaya neden olabileceğini düşündüğünden bu uygulamayı desteklemektedir [2]. Ülkemizde bireysel görüsslere dayalı bu obstetrik uygulamaların yerini, dünyada; Amerika Birleşik Devletleri (ABD), Kanada, İngiltere, Avustralya ve birçok Avrupa ülkesi kanıta dayalı uygulamalara bırakmıştır. Kanıta daya11 uygulamalar sağlık bakım hizmetlerinin her alanında olduğu gibi, doğum eyleminde destek ve bakım sağlayıcılar için önemli standartlar oluşturulmasına yardımcı olacaktır [3].

Ülkemizde; doğum sırasında oral beslenme kısıtlanmasının gerekçesi, Mendelson'ın 1946'da doğum sırasında gastrik boşalmadaki gecikmenin aspirasyon pnömonisine neden olabileceğine ve asidik mide içeriğinin ölüm riskini arttırabileceğine ve bu durumun da maternal 
komplikasyonların şiddetini belirleyebileceğine yönelik teorisine dayanmaktadır. Bireyde oral alımı kısıtlamanın amacı, gastrik boşalmay1 sağlayarak anestezi altındayken mide içeriğinin akciğerlere aspire olma riskini azaltmaktır [4-6]. Çünkü genel anestezik ilaçlar; akciğerleri koruma fonksiyonu olan refleksleri azaltarak mide içeriğinin aspire edilmesine ve gebenin yaşamını tehdit eden önemli solunum problemlerinin gelișmesine neden olabilmektedir [7, 8]. Sezaryen operasyonlarının çoğu, geçirilmiş eski sezaryen endikasyonu nedeni ile ameliyat öncesi (pre-op) aç birakılırken, normal doğum planlanan gebelerde ise; acil sezaryen ihtimali nedeniyle, oral kisitlanmaya gidilmektedir. Bununla birlikte ebeler ve bazı kadın doğum uzmanları tarafindan eylem sirasında bireyi oral yolla beslemenin anneye, fetüse ve eylem sürecine zarar verebileceği inancı bulunmaktadır $[2,9]$. Bu nedenle ülkemizde geleneksel olarak hastaların doğum eyleminde oral katı ve siv1 besin alımı engellenmektedir. Ancak çalıșmalar, akciğer aspirasyonun modern anestezinin nadir görülen komplikasyonlarından olduğunu; açlık süresi, mide hacmi ve asiditesi arasında zayıf bir ilişki olduğunu ve bu nedenle uzun süren açlık döneminin gerekli olmadığını ileri sürmektedir $[5,6,13]$.

Cochrane veri tabanı sistematik incelemesinde ise Mendolson'un doğum sirasında aspirasyon pnömonisini değerlendiren veriler yetersiz bulunmuş olup aspirasyon insidansı incelemeleri vakaların neredeyse tamamının anestezi uygulama hatalarından kaynaklandığ1nı göstermektedir [10, 11]. Yapılan çalıșmalar ve güncel verilerle; ABD, Kanada, İngiltere, Avustralya ve birçok Avrupa ülkelerinin çeşitli merkezlerinde, doğum eylemi sırasında kadınların ağızdan bisküvi, bal, yoğurt, açık çay, kahve, su gibi bazı gıdaları almalarına izin verilmektedir. Ülkemizde ise her türlü oral alım yasak olup, kadınların enerji ihtiyaçlarının giderilmesi için genelde glikoz içerikli solüsyonlar intravenöz (IV) olarak verilmektedir [9, 12-15]. $\mathrm{Bu}$ konuda Amerikan Obstetriyen ve Jinekologlar Birliği'ne (ACOG) göre; aspirasyon ve müdahaleli doğum riski olmayan gebeler oral tanesiz sıvı besin tüketebilirler, fakat içerisinde partikül bulunan sıvilardan (çorba vb.) kaçınmalıdırlar. Ek olarak, sezaryen doğum planlanan ve komplikasyonu olmayan gebelerde ise anesteziden iki saat önceye kadar oral yolla berrak/tanesiz sıvı verilebileceği önerilmekte$\operatorname{dir}[16]$.

Doğum eyleminde kadınların oral sıvı ve besin alımının sinırlandırılması, annede ve fetüste bazı komplikasyonlara sebep olabildiğini bildiren çalışmalar da bulunmaktadır $[6,10,17$,
18]. Bu derlemede, ülkemizde yaygın olarak uygulanan oral sıv1 ve besin alımının sınırlandırılmasının anne ve bebek açısından değerlendirilmesi, bu konuda kanıta dayalı tıp uygulamaları ve doğum eyleminde kadının beslenme gereksinimleri incelenecektir. Bununla birlikte; doğum eyleminde destek ve bakım sağlayıcılarda farkındalık sağlaması ve uygulamalara yol göstermesi hedeflenmektedir.

Doğum Eyleminde Beslenme: Doğum eyleminin erken evresinde yükselen prolaktin seviyesi annenin iștahını arttırırken, doğum eylemi ilerledikçe oksitosinin artmasıyla kadının yeme isteği azalır [6, 19]. Eğer kadın aç ise doğum eyleminin başlaması güçtür. Ancak doğum eylemi aktif olarak başladığında kadınlar bir şey yemek istemezler. Bir kadının yemek yemeye ihtiyaç duyması, eylemin başlaması ya da ilerlemesi için kadının gerçekten besine, enerjiye gereksinimi olduğunu gösterir. Kadına bu durumda bir şeyler yiyip içmesine izin verilmezse doğum eylemi başlamayabilir ya da ilerlemeyebilir [20].

İngiltere'de 301 kadın üzerinde gerçekleştirilen randomize kontrollü çalışmada, yeme ve içmesi serbest bırakılan gebelerle, sadece buz parçacığı verilen gebeler karşılaştırılmıştır. Yeme ve içmesi serbest bırakılan kadınların \%80'i doğum eyleminin erken döneminde yemeyi tercih ederken, servikal dilatasyon yaklaşık 5 cm'e ulaştığında yeme içmeyi sonlandırmayı tercih ettikleri bildirilmektedir. Doğum sonu dönemde yeme içme serbest olan grubun $\% 97$ 'si bu uygulama nedeniyle memnun olduklarını bildirirken, sadece buz parçacı ğı verilen grubun çoğunluğu (\%57) hayal kırıklığ yaşadığını bildirmiştir [6].

Benzer olarak Avusturalya'da yapilan bir çalışma da kadınların \%47'si doğum eyleminin erken evresinde yemeyi tercih ederken \%53'ü tercih etmemiştir [21]. Yapılan başka bir çalışma da İskoçya'da 182 kadından \%70'i doğum süresince bir şeyler yiyip içmek istediğini belirtmektedir. Bununla birlikte çalışma kadınlarda yeme içme firsatının verilmesiyle memnuniyetin arttığını göstermektedir [22]. Sonuç olarak çoğu çalışma kadının doğumun erken evresinde yeme içmeyi istediği, çok azının aktif eylem sırasında yemeyi tercih ettiği görülmektedir. Bununla birlikte çalışmalar kadınların yeme içme konusunda sınırlandırılmak istemediklerini, sınırlandırılmanın memnuniyetlerini düşürdüklerini göstermektedir [6].

\section{Doğum Eyleminde Oral Beslenmenin Anne Açısından Değerlendirilmesi: Doğum eyle- minde oral beslenmenin sinırlandırılması Men-}


delson'un 1946'daki çalıșmalarına dayand1rılmıştır. Son yayınlarda narkotik analjezikler kullanılmadıkça, doğum eylemindeki kadınlarda midenin boşalmasında gecikme olmadığı, doğum eylemi sırasında siklikla yașanan anksiyete, stres ve ağrının mide boşalmasında etkili olduğu tespit edilmiştir $[4,6,18]$. Bununla birlikte mide içeriğinin volümü ve asiditesini mide sekresyonu, alınan gidalar ve midenin boşalma hızı etkilediği bilinmektedir. Midenin boșalmasında su için yarılanma zamanı yaklaşık 10 dakikadır. Partikülsüz sıvıların \%95'i yaklașık bir saat içinde mideyi boşaltır ve katı gıdaların mideyi boşaltma hızı sabittir ve yiyecekler alındıktan bir saat sonra mide boşalmaya başlar. Yiyeceklerin \%50'si iki saat içinde düedonuma geçer. Ayrıca kadın ne kadar zaman aç kalırsa kalsın hiçbir zaman mide tam olarak boşalmamaktadır. Ancak açlık mide asiditesini arttıran bir faktördür. Çünkü açlık durumunda, mide sekresyonu uyarılmakta ve hem mide volümü artmakta hem de $\mathrm{pH}$ düşmektedir. Dolayısıyla bu durum aspirasyon riskini arttırabilmektedir $[14,23,24]$. Bununla birlikte; açlık sadece aspirasyon riskini arttırmakla kalmayı hem eylem sirasinda hem sonrasinda da bazı problemlere neden olabilmektedir.

Kadınların ağızdan sıvı ve besin alımının sınırlandırılması, annede açlık ve susuzluk hissine, ketosiz, hiponatremi, hipoglisemi, uzamış doğum eylemi, bulantı ve kusma, dehidratasyon, müdahaleli doğum ve doğum sonu kanamaya, hastanede yatış süresinin artmasına anne memnuniyetsizliğine, emzirme sürecinde başarısızlığa neden olabilmektedir. Kadında açlığa bağlı stres seviyesinde artma da ketosizi şiddetlendirmektedir. Aynı zamanda açlık ağnı algılamasını da etkilemekte, kadın baș ağrısı, bulantı, hareket kısıtlı̆̆ı, kateter yerinde lokal ağrı gibi sorunlar yaşamaktadır. Tüm bu olumsuz gelişmeler kadının eyleme uyumunu zorlaştırarak eylemin ilerleyişini etkilemektedir $[10,14,17$, 25].

Ergöl ve arkadaşlarının yaptığ çalışmada s1vi gida desteği verilen müdahale grubundaki kadınların ortalama eylem süresi ile ağızdan bir şey verilmeyen kontrol grubundaki kadınların eylem süreleri arasında yaklaşık iki saatlik bir fark saptanmıştır [15]. Benzer şekilde $301 \mathrm{ka}-$ dını içeren randomize kontrollü başka bir çalışmada doğum eyleminde yemenin serbest olduğu grup da doğum eylemi süresi önemli oranda az bulunmuştur [6].

Beş randomize kontrollü çalışmayı kapsayan 3120 kadını içeren Cochrane sistematik incelemesi sonuçlarına göre; yeme sınırlandır- ması yapılan ve yapılmayan kadınlar arasında görülen riskler arasında anlamlı bir farklılık olmadığını göstermektedir. Bu durumda ise kadınların yemeyi kendi isteğine bırakılmasının doğru olduğu, yasak getirilmemesinin gerektiği belirtilmektedir [10].

\section{Oral Beslenmenin Yasaklanmasının Bebek} Açısından Değerlendirilmesi: Doğum eylemi sirasında oral beslenmenin yasaklanması kadında kan glikoz seviyesindeki düşüşe, bu düşüş de fetüste solunum ve hareketliliğinin bozulmasina neden olabilmektedir. Bu problemler haricinde doğum eyleminde yeme içmenin bebeğe etkisi konusunda yeterli çalışmaya rastlanmamiştır [6]. Singata, Tranmer ve Gyte tarafindan doğum eylemi sürecinde katı ve sıvı oral alımı kısıtlamasının yararları ve zararları değerlendirildiği Cochrane sistematik incelemesinde; sadece su içmesine izin verilen, sadece karbonhidratlı içecekler almasına izin verilen ve yeme içmesine izin verilen gebeler karşılaştırılmıştır [10]. Çalışma sonrasında gebelerde oral kısıtlanmanın gereksiz olduğu, yenidoğanların apgar skorlarının 7'nin altında olması ve yenidoğanın yoğun bakım ünitesine kabul edilme gereksinimleri arasında anlamlı bir fark olmadığ 1 bulunmuştur.

\section{Anne ve Bebek Açısından İntravenöz Bes-} lenmenin Etkileri: Ketonüri durumlarında, eylemdeki kadına müdahale etmek gerektiği inancı yaygın olduğundan, bazen kadınlar ağızdan kalori almak için cesaretlendirilmekte bazen de IV sıvi tedavisi verilmektedir. Ketosizi önlemek için yapılan IV tedaviler ise; annede hiponatremi, hiperglisemi, fetüste iyatrojenik hiperinsulinemi buna bağlı olarak yenidoğanda hipoglisemi, fetüs serum $\mathrm{pH}$ 'sında düşme ve fetal laktat seviyesinde artmaya neden olduğu bilinmektedir. [15, 25, 26]. Randomize kontrollü 9 adet çalışmayı içeren Cochrane sistematik incelemesinde, oral sivi kisitlaması yapılan gebelere rutin uygulanan IV mayilerin doğum süresini azalttığ 1 , ancak dekstroz içeren mayilerin gebe ve yenidoğanda sodyum seviyelerini düşürerek hiponatremiye yol açtığ 1 bulunmuştur. Bununla birlikte yapılan çalıșmaların yetersiz olduğu daha fazla çalışmaya gereksinim olduğu açıklanmıştır [10].

\section{SONUÇ}

Son zamanlarda randomize kontrollü ça1ışmaları içeren sistematik incelemeler doğum eyleminde oral beslenmesinin kisitlanması konusunda Mendelson'un teorilerinin geçersizliğini, bu konuda verilerin yetersizliğini ortaya koymaktadır $[6,10,18]$. Bu nedenle ülkemizde 
yaygin olan oral beslenmenin kisitlanması uygulamasının yerine, yeme içme kadının isteğine bırakılması gerekmektedir. Nitekim yapılan çalışmalarda kadının aktif doğum eyleminde yemek yemeyi istemediği, eğer istiyorsa doğum eyleminin ilerlemesi için gerçekten enerjiye gereksinim duyduğunu göstermektedir. Özetle; doğum eylemi doğal bir süreçtir ve müdahele etmek, sınırlama getirmek yerine kadının bedenini yönetmesine, isteklerinin yerine getirilmesine destek verilmelidir [20]. ACOG'a göre de risksiz durumlarda gebelerin ve sezaryen planlananların ise anesteziden iki saat önceye kadar oral berrak/tanesiz siv1 tüketebileceği önerisinde bulunmaktadır [16]. Bu konuda kanıtları güçlendirmek için daha fazla nitelikli çalışmalara gerek duyulmaktadır.

\section{KA Y N A KL A R}

1. Rathfisch G, Doğum Eylemi. İçinde: Beji NK, editör. Kadın Sağlı̆̆ı ve Hastalıkları. 1. Baskı. Nobel Tip Kitapevleri. Istanbul: 2015. s.312-4.

2. Parsons M. A midwifery practice dichotomy on oral intake in labour. Midwifery 2004; 20: 72-81.

3. Rathfisch GY, Güngör İ. Doğum eyleminin birinci evresinin yönetiminde kanıta dayalı uygulamalar. HEMAR-G 2009; 11(3):53-64.

4. Mendelson CL. The aspiration of stomach contents into lungs during obstetrics anesthesia. Anesthesiology 1946; 7(6):694-5.

5. Baril P, Portman H. Preoperative fasting: Knowledge and perceptions. AORN Journal 2007; 86(4): 609-17.

6. Gyte G. NCT Evidence Based Briefing: Eaiting and drinking in labour. New Digest 2007; 25-9.

7. Demirdağ H, Karagöz S. Ameliyat öncesi besin/sivı kısitlamasina ilişkin hastaların deneyimleri ve hemşirelerin konu ile ilgili bilgi ve uygulamalart. F N Hem Derg 2015; 23(1):1-10.

8. Stuart PC. The evidence base behind modern fasting guidelines. Best Practise Research Clinical Anaesthesiology 2006; 20(3):457-69.

9. Parsons M. Policy or tradition: oral intake in labour. The Australian Journal of Midwifery 2001; 14(3): 6-12.

10. Singata M, Tranmer J, Gyte GM. Restricting oral fluid and food intake during labour. Cochrane Database of Systematic Reviews 2013; (8): CD003930.
11. Başgöl Ş, Beji NK. Doğum eyleminin birinci evresinde sık yapılan uygulamalar ve kanıta dayalı yaklaşım. Düzce Üniversitesi Sağllk Bilimleri Enstitüsü Dergisi 2015; 5(2): 32-9.

12. Micheal S, Reilly C. Policies for oral intake during labour: A survey of maternity units in England and Walles. Anesthesia 1991; 46(12): 1071-3.

13. Tranmer JE, Hodnett ED, Hannah ME, Stevens BJ. The effect of unrestricted oral carbohydrate intake on labor progress. J Obstet Gynecol Neonatal Nurs 2005; 34(3): 319-28.

14. Maharaj D. Eating and drinking in labor: Should it be allowed? Eur J Obstet Gynecol REPROD Biol 2009; 146(1): 3-7.

15. Ergöl S, Eroğlu K, Tașkın L. Doğum eylemindeki kadlna yaklaşım: A ğızdan beslenme. Turkiye Klinikleri J Nurs Sci 2012; 4(1):23-9.

16. Oral intake during labor. ACOG Committee Opinion No. 441. American College of Obstetricians and Gynecologists. Obstet Gynecol 2009; 114:714.

17. Ludka LM, Roberts CC. Eating and drinking in labor. Journal of Nurse Midwifery 1993; 38(4): 199-207.

18. King R, Glover P, Byrt K, Nocella L. Oral nutrition in labour: Whose choice is it anyway? A review of the literature. Midwifery 2011; 27(5): 674-86.

19. McNabb M. Changes in maternal food appetite and metabolism in labour and the shift from fetal to neonatal metabolism. In: Champion P, McCormick C, editors. Eating and drinking in labour. Oxford: Books for Midwives; 2002. pp. 46-110.

20. Rathfisch G. Doğal Doğum Felsefesi. Nobel Tip Kitapevleri. Istanbul: 2012. s. 3,124-5.

21. Parsons M, Bidewell J, Nagy S. Natural eating behavior in latent labor and its effect on outcomes in active labor. J Midwifery Womens Health 2006; 51(1): 1-6.

22. Armstrong TS, Johnston IG. Which women want food during labour? Results of an audit in a Scottish DGH. Health Bull (Edinb) 2000; 58(2): 141-4.

23. Brady M, Kinn S, Stuart P. Preoperative Fasting for Adults to Prevent Perioperative Complications. Cochrane Database of Systematic Reviews 2003;(4): CD004423.

24. Levy DM. Pre-Operative Fasting 60 Years on from Mendelson, Continuing Education in Anaesthesia, Critical Care \& Pain 2006; 6(6): 215-8.

25. Toohill J, Soong B, Flenady V. Interventions For Ketosis During Labour. (Protocol) The Cochrane Database Of Systematic Reviews 2008; CD004230.

26. Kubli M, Scrutton MJ, Seed PT, O'Sullivan G. An Evaluation of isotonic lsports drinks during labor. Anesth Analq 2002; 94 (2): 404-8. 